\title{
LAND REFORM ATAS TANAH EKS HGU PT RSI DI KABUPATEN CIAMIS SUATU KAJIAN HUKUM
}

\author{
Oleh : HENDRA SUKARMAN, S.H., S.E., M.H. ${ }^{*}$
}

\begin{abstract}
Iplementasi of the mandate of the People's Consultative Assembly Decree of the Republic of Indonesia (MPR RI) is the holding of Land Reform, which is the mandate of TAP MPR No. IX / MPR / 2001 on Agrarian Reform. Soil is a major component in the Land Reform, then basically the designated land as the object Land Reform today in Ciamis is state land ex HGU RSI from various sources according to the legislation can be used as objects of Land Reform. Therefore the supply of land is a strategic step for the success of Land Reform.

That the property rights to land can only be owned by Indonesian citizens and or the civil equivalent to the legal entity that is, it is in accordance with the Law article 21 (1) (2). Soil is a major component in the Land Reform, then basically the designated land as the object Land Reform today in Ciamis is state land ex HGU RSI from various sources according to the legislation can be used as objects of Land Reform.
\end{abstract}

\begin{abstract}
ABSTRAK
Iplementasi dari mandat Ketetapan Majelis Permusyawaratan Rakyat Republik Indonesia (TAP MPR RI) adalah dengan diadakannya Land Reform, yang merupakan amanat dari TAP MPR Nomor IX/MPR/2001 Tentang Pembaruan Agraria. Tanah merupakan komponen utama dalam Land Reform , maka pada dasarnya tanah yang ditetapkan sebagai objek Land Reform sekarang ini di Kabupaten Ciamis adalah tanah-tanah negara eks HGU RSI dari berbagai sumber yang menurut peraturan perundang-undangan dapat dijadikan sebagai objek Land Reform . Karenanya kegiatan penyediaan tanah merupakan langkah strategis bagi keberhasilan Land Reform.

Bahwa hak milik atas tanah hanya boleh dimiliki oleh WNI dan atau yang secara perdata dipersamakan dengan orang yakni badan hukum, hal ini sesuai dengan UUPA pasal 21 (1) (2). Tanah merupakan komponen utama dalam Land Reform , maka pada dasarnya tanah yang ditetapkan sebagai objek Land Reform sekarang ini di Kabupaten Ciamis adalah tanah-tanah negara eks HGU RSI dari berbagai sumber yang menurut peraturan perundang-undangan dapat dijadikan sebagai objek Land Reform.
\end{abstract}

\footnotetext{
*) *) Dosen Fakultas Hukum Universitas Galuh
} 


\section{PENDAHULUAN}

Iplementasi dari mandat Ketetapan Majelis Permusyawaratan Rakyat Republik Indonesia (TAP MPR $\mathrm{RI})$ adalah dengan diadakannya Land Reform, yang merupakan amanat dari TAP MPR Nomor IX/MPR/2001 Tentang Pembaruan Agraria dan Pengelolaan Sumberdaya Alam dan Keputusan MPR RI Nomor 5/MPR/2003 tentang Penugasan kepada MPR-RI untuk Menyampaikan Saran atas Laporan Pelaksanaan Keputusan MPR-RI oleh Presiden, DPR, BPK dan MA pada Sidang Tahunan MPR-RI Tahun 2003. Salah satu butir saran dimaksud kepada Presiden Republik Indonesia, terkait dengan perlunya Penataan Struktur Penguasaan, Pemilikan, Pemanfaatan dan Penggunaan Tanah.

Land Reform atau disebut juga dengan Pembaruan Agraria adalah proses yang berupa kegiatan penetapan hak garapan dan hak hunian Masyarakat serta melakukan restrukturisasi (penataan ulang susunan) kepemilikan, penguasaan, dan penggunaan sumber-sumber agraria (khususnya tanah). Dalam pasal 2 TAP MPR RI Nomor IX/MPR/2001 dijelaskan bahwa "Pembaruan Agraria mencakup suatu proses yang berkesinambungan berkenaan dengan penataan kembali penguasaan, pemilikan, penggunaan dan pemanfaatan sumberdaya tanah , dilaksanakan dalam rangka tercapainya kepastian dan perlindungan hukum serta keadilan dan kemakmuran bagi seluruh rakyat Indonesia".

Rangkaian kegiatan meyeluruh dari land reform di Indonesia dilaksanakan melalui 2 (dua) langkah yaitu :

1. Penataan kembali politik dan hukum pertanahan yang didasarkan pada: Pancasila, Undang-Undang Dasar 1945, Bhineka Tunggal Ika dan kerangka Negara Kesatuan Republik Indonesia.

2. Proses Penyelenggaraan Land Reform Plus, yaitu Penetapan aset tanah dan Hunian tetap bagi Penggarap dan Penghuni obyek asset reform juga penataan aset tanah bagi masyarakat dan Penataan akses masyarakat terhadap sumber-sumber ekonomi dan politik yang memungkinkan masyarakat untuk memanfaatkan tanahnya secara optimal.

\section{Pembahasan}

\section{Dasar Hukum}

1. Undang-Undang Dasar 1945 Pasal 27 (2), Pasal 28 dan Pasal 33 ayat (1) amandemen keempat

2. Tap Majelis Permusyawaratan Rakyat Nomor IX/ MPR/ 2001 
3. Keputusan Majelis Permusyawaratan Rakyat Nomor 5/MPR/2003

4. Undang-Undang Pokok Agraria 1960 (UUPA 1960)

5. Undang-undang Nomor 56 Prp Tahun 1960

6. Peraturan Pemerintah Nomor 224 Tahun 1961 tentang Pelaksanaan Pembagian Tanah Dan Pemberian Ganti Kerugian.

7. Peraturan Presiden Nomor 10 Tahun 2006 Tentang Badan Pertanahan Nasional.

8. Peraturan Pemerintah Nomor 10 Tahun 1996 tentang Hak Tanggungan Atas Tanah Beserta Benda-Benda Yang Berkaitan Dengan Tanah.

9. Peraturan Pemerintah Nomor 24 Tahun 1997 Tentang Pendaftaran Tanah.

\section{Maksud dan Tujuan Land Reform}

Maksud Land Reform :

1. Menetapkan garapan masyarakat menjadi garapan tetap masyarakat.

2. Menetapkan hunian masyarakat menjadi hunian tetap masyarakat.

3. Menciptakan kesejahteraan masyarakat yang berbasis pertanahan.

4. Menata kehidupan masyarakat yang lebih berkeadilan.
5. Meningkatkan berkelanjutan sistem kemasyarakatan kebangsaan dan kenegaraan Indonesia, serta

\section{Tujuan Land Reform :}

Sesuai dengan amanat UndangUndang Dasar 1945 Pasal 27 Ayat (2) yang berbunyi :tiap tiap warga negara berhak atas pekerjaan dan penghidupan yang layak bagi kemanusian. Di samping itu tujuan lainnya dari Land reform adalah :

1. Memberikan alas hukum yang pasti atas garapan masyarakat.

2. Membuat alas hukum yang jelas atas tanah yang telah menjadi hunian penggarap lahan.

3. Menciptakan dan menjamin masyarakat untuk berkumpul dan berserikat.

4. Menciptakan Koperasi Pertanian yang handal.

5. mengurangi kemiskinan.

6. menciptakan lapangan kerja.

7. memperbaiki akses masyarakat kepada sumber-sumber ekonomi, terutama tanah.

8. menata ulang penguasaan pemilikan, penggunaan dan pemanfaatan tanah dan sumbersumber tanah.

9. mengurangi sengketa dan konflik pertanahan. 
10. memperbaiki dan menjaga kualitas lingkungan hidup.

11.meningkatkan ketahanan pangan dan energi terbarukan masyarakat.

12. Meningkatkan

kesejahteran masyarakat.

\section{Prinsip-Prinsip Land Reform}

1. Memuliakan Alloh dan mempertinggi derajat manusia.

2. memelihara dan mempertahankan keutuhan Negara Kesatuan Republik Indonesia;

3. menghormati dan menjunjung tinggi hak asasi manusia;

4. menghormati supremasi hukum dengan mengakomodasi keanekaragaman dalam unifikasi hukum;

5. mensejahterakan rakyat, terutama melalui peningkatan kualitas sumberdaya manusia Indonesia;

6. mengembangkan demokrasi, Kelembagaan masyarakat, kepatuhan hukum, transparansi dan optimalisasi partisipasi rakyat;

7. mewujudkan keadilan dalam penguasaan, pemilikan, penggunaan, pemanfaatan, dan pemeliharaan sumberdaya tanah dan sumberdaya alam;

8. memelihara keberlanjutan yang dapat memberi manfaat yang optimal, baik untuk generasi sekarang maupun generasi mendatang, dengan tetap memperhatikan daya tampung dan dukung lingkungan;

9. melaksanakan fungsi sosial, kelestarian, dan fungsi ekologis sesuai dengan kondisi sosial budaya setempat;

10. meningkatkan keterpaduan dan koordinasi antarsektor pembangunan dalam pelaksanaan pembaruan tanah dan pengelolaan sumberdaya alam;

11. mengakui dan menghormati hak masyarakat hukum adat dan keragaman budaya bangsa atas sumberdaya tanah dan sumberdaya alam;

12. mengupayakan keseimbangan hak dan kewajiban negara, pemerintah (pusat, daerah provinsi, kabupaten/kota, dan desa atau yang setingkat), masyarakat dan individu;

13. melaksanakan desentralisasi berupa pembagian kewenangan di tingkat nasional, daerah provinsi, kabupaten/kota, dan desa atau yang setingkat, berkaitan dengan alokasi dan manajemen sumberdaya tanah dan sumberdaya alam.

\section{Arah Kebijakan Land Reform}

1. Melakukan Penetapan garapan masyarak menjadi garapan tetap 
masyarakat dan hunian masyarakat menjadi hunian tetap masyarakat, agar secara hukum masyarakat terlindungi hak atas tanahnya.

2. Melaksanakan penataan kembali penguasaan, pemilikan, penggunaan dan pemanfaatan tanah (landreform) yang berkeadilan dengan memperhatikan kepemilikan tanah untuk rakyat, baik tanah pertanian maupun tanah perkotaan.

3. Menyelenggarakan dan membina Koperasi Petani yang juga merupakan bagian menyeluruh dari adanya Koperasi Nasional agar tetap menjadi soko guru Perekonomian Indonesia.

4. Menyelenggarakan pendataan pertanahan melalui inventarisasi dan registrasi penguasaan, pemilikan, penggunaan dan pemanfaatan tanah secara komprehensif dan sistematis dalam rangka pelaksanaan landreform.

5. Menyelesaikan konflik-konflik yang berkenaan dengan sumberdaya tanah yang timbul selama ini sekaligus dapat mengantisipasi potensi konflik dimasa mendatang guna menjamin terlaksananya penegakan hukum dengan didasarkan atas prinsip-prinsip Land Reform .
6. Memperkuat kelembagaan dan kewenangannya dalam rangka mengemban pelaksanaan pembaruan tanah dan menyelesaikan konflik-konflik yang berkenaan dengan sumberdaya tanah yang terjadi.

7. Mengupayakan pembiayaan dalam melaksanakan program pembaruan tanah dan penyelesaian konflikkonflik sumberdaya tanah yang terjadi.

\section{Objek Land Reform}

Tanah merupakan komponen utama dalam Land Reform , maka pada dasarnya tanah yang ditetapkan sebagai objek Land Reform sekarang ini di Kabupaten Ciamis adalah tanah-tanah negara eks HGU RSI dari berbagai sumber yang menurut peraturan perundang-undangan dapat dijadikan sebagai objek Land Reform . Karenanya kegiatan penyediaan tanah merupakan langkah strategis bagi keberhasilan Land Reform. Salah satu contoh sumber tanah objek Land Reform adalah tanah terlantar yang mana sudah tidak digarap lagi oleh pemilik HGU dan HGU nya tersebut tidak diperpanjang lagi. Menurut Pasal 9 PP Nomor 11 Tahun 2010 tentang Penertiban dan Pendayagunaan Tanah Terlantar, tanah terlantar yang sudah ditetapkan menjadi tanah negara akan menjadi salah satu objek Land Reform. 


\section{Subjek Land Reform}

Bahwa hak milik atas tanah hanya boleh dimiliki oleh WNI dan atau yang secara perdata dipersamakan dengan orang yakni badan hukum, hal ini sesuai dengan UUPA pasal 21 (1) (2).

1. Untuk penerima hak milik atas tanah perorang dalam rangka Land reform berlaku ketentuan sebagai berikut :

a. Syarat umum

Berdasarkan pada Pasal 8 PP 224 Tahun 1961 Subyek penerima redistribusi tanah adalah mempunyai syarat Umum adalah :

1) Dengan mengingat pasal $9 \mathrm{~s} / \mathrm{d}$ 12 dan pasal 14, maka tanahtanah yang dimaksudkan dalam pasal 1 huruf $a, b$ dan $c$ dibagibagikan dengan hak milik kepada para petani oleh Panitia Landreform Daerah Tingkat II yang bersangkutan, menurut prioritet sebagai berikut :

a) Penggarap yang mengerjakan tanah yang bersangku$\tan$;

b) Buruh tani tetap pada bekas pemilik, yang mengerjakan tanah yang bersangkutan;

c) Pekerja tetap pada bekas pemilik tanah yang bersangkutan; a) Penggarap yang belum sampai 3 tahun mengerjakan tanah yang bersangkutan;

b) Penggarap yang mengerjakan tanah hak pemilik;

c) Penggarap tanah-tanah yang oleh Pemerintah diberi peruntukan lain berdasarkan pasal 4 ayat (2) dan (3);

d) Penggarap yang tanah garapannya kurang dari 0,5 hektar;

e) Pemilik yang luas tanahnya kurang dari 0,5 hektar; 1.Petani atau buruh tani lainnya.

2) Jika didalam tiap-tiap prioritet tersebut dalam ayat (1) pasal ini terdapat :

a. petani yang mempunyai ikatan keluarga sejauh tidak lebih dari dua derajat dengan bekas pemilik, dengan ketentuan sebanyakbanyaknya 5 orang;

b. petani yang terdaftar sebagai Veteran;

c. petani janda pejuang kemerdekaan yang gugur;

d. petani yang menjadi korban kekacauan, maka kepada mereka itu diberikan pengutamaan diatas petani- 
petani lain, yang ada didalam golongan prioritet yang sama.

3) Yang dimaksudkan dengan "petani", ialah orang, baik yang mempunyai maupun tidak mempunyai tanah sendiri, yang mata pencaharian pokoknya adalah mengusahakan tanah untuk pertanian.

4) Yang dimaksudkan dengan "penggarap", adalah petani, yang secara sah mengerjakan atau mengusahakan sendiri secara aktif tanah yang bukan miliknya, dengan memikul seluruh atau sebagian dari risiko produksinya.

5) Yang dimaksudkan dengan "buruh tani tetap", adalah petani, yang mengerjakan atau mengusahakan secara terus menerus tanah orang lain dengan mendapat upah.

6) Yang dimaksudkan dengan "pekerja tetap", adalah orang yang bekerja pada bekas pemilik tanah secara terus menerus.

b. Syarat Khusus

Dalam Pasal 9 PP 224 tahun 1961 disebutkan :

Untuk mendapat pembagian tanah, maka para petani yang dimaksudkan dalam pasal 8 harus memenuhi :

a. Syarat-syarat umum:

Warga Negara Indonesia, bertempat tinggal di Kecamatan tempat letak tanah yang bersangkutan dan kuat kerja dalam pertanian.

b. Syarat-syarat khusus:

Bagi petani yang tergolong dalam prioritet $\mathrm{a}, \mathrm{b}, \mathrm{e}, \mathrm{f}$ dan $\mathrm{g}$ : telah mengerjakan tanah yang bersangkutan sekurang-kurangnya 3 tahun berturut-turut; bagi petani yang tergolong dalam prioritet $\mathrm{d}$ : telah mengerjakan tanahnya 2 musim berturut-turut; bagi para pekerja tetap yang tergolong dalam prioritet c: telah bekerja pada bekas pemilik selama 3 tahun berturut-turut.

2. Sedangkan penerima hak milik atas tanah berupa badan hukum dalam rangka Land Reform adalah Koperasi. Hal ini sesuai dengan :

1) pasal 14(3) huruf $d$ dan pasl 17 ayat (1)(2)(3)(4) PP 224 Tahun 1961. Dimana anggota koperasi tersebut merupakan masyarakat penerima penetapan garapan dan hunian tetap atas tanah hak milik mereka atas tanah yang menjadi obyek land reform.

2) Koperasi merupakan semangat gotong royong yang merupakan roh keswadayaan dan soko guru 
perekonomian di Indonesia. Sesuai dengan Pasal 33 ayat (1) UUD 45 "Perekonomian disusun sebagai usaha bersama berdasar atas azas kekeluargaan."

3) bahwa koperasi adalah merupakan kehendak dan keinginan alamiah masyrakat berkumul dan menghimpun diri sesuai dengan Pasal 28 UUD 45 yang berbunyi " Kemerdekaan berserikat dan berkumpul, mengeluarkan pikiran dengan lisan dan tulisan dan sebagainya ditetapkan dengan Undangundang.

\section{Kesimpulan}

Dasar Hukum dari Landre Form adalah UUD 1945 Pasal 27 (2), Pasal 28 dan Pasal 33 ayat (1) amandemen keempat, Tap MPR Nomor IX/ MPR/ 2001, Keputusan MPR Nomor 5/MPR/2003, Undang-Undang Pokok Agraria 1960 (UUPA 1960), Undangundang Nomor 56 Prp tahun 1960, PP 224 tahun 1961, Perpres No. 10 Tahun 2006, PP No. 10 tahun 1996, PP No. 24 Tahun 1997.

Bahwa hak milik atas tanah hanya boleh dimiliki oleh WNI dan atau yang secara perdata dipersamakan dengan orang yakni badan hukum, hal ini sesuai dengan UUPA pasal 21 (1) (2). Tanah merupakan komponen utama dalam Land Reform, maka pada dasarnya tanah yang ditetapkan sebagai objek Land Reform sekarang ini di Kabupaten Ciamis adalah tanah-tanah negara eks HGU RSI dari berbagai sumber yang menurut peraturan perundang-undangan dapat dijadikan sebagai objek Land Reform

\section{DAFTAR PUSTAKA}

Undang-Undang Dasar 1945 Pasal 27 (2), Pasal 28 dan Pasal 33 ayat (1) amandemen keempat.

Tap Majelis Permusyawaratan Rakyat Nomor IX/ MPR/ 2001.

Keputusan Majelis Permusyawaratan Rakyat Nomor 5/MPR/2003.

Undang-Undang Pokok Agraria 1960 (UUPA 1960).

Undang-undang Nomor 56 Prp Tahun 1960.

Peraturan Pemerintah Nomor 224 Tahun 1961 tentang Pelaksanaan Pembagian Tanah Dan Pemberian Ganti Kerugian.

Peraturan Presiden Nomor 10 Tahun 2006 Tentang Badan Pertanahan Nasional.

Peraturan Pemerintah Nomor 10 Tahun 1996 tentang Hak Tanggungan Atas Tanah Beserta BendaBenda Yang Berkaitan Dengan Tanah.

Peraturan Pemerintah Nomor 24 Tahun 1997 Tentang Pendaftaran Tanah 
